\title{
CHOICE OF TRACERS FOR THE EVALUATION OF SPRAY DEPOSITS
}

\author{
Luiz Antonio Palladini ${ }^{1}$; Carlos Gilberto Raetano ${ }^{2 *}$; Edivaldo Domingues Velini ${ }^{3}$ \\ ${ }^{1}$ EPAGRI/Estação Experimental de Caçador, C.P. 591 - 89500-000 - Caçador, SC - Brasil. \\ ${ }^{2}$ UNESP/FCA - Depto. de Produção Vegetal/Defesa Fitossanitária - Fazenda Lageado, C.P. 237 - 18603-970 - \\ Botucatu, SP - Brasil. \\ ${ }^{3}$ UNESP/FCA - Depto. de Produção Vegetal/Agricultura. \\ *Corresponding author<raetano@fca.unesp.br>
}

ABSTRACT: Tracer substances, used to evaluate spraying effectiveness, ordinarily modify the surface tension of aqueous solutions. This study aimed to establish a method of using tracers to evaluate distribution and amount of spray deposits, adjusted to the surface tension of the spraying solution. The following products were tested: $0.15 \%$ Brilliant Blue, $0.15 \%$ Saturn Yellow in 0.015\% Vixilperse lignosulfonate, and $0.005 \%$ sodium fluorescein, and mixtures of Brilliant Blue plus Saturn Yellow and Brilliant Blue plus sodium fluorescein at the same concentrations. Solutions were deposited on citrus leaves and stability was determined by measuring fluorescence and optical density of solutions without drying, dried in the dark and exposed to sunlight for 2 , 4 and $8 \mathrm{~h}$. These values were compared to those obtained directly in water. The static surface tension of the tracer solution was determined by weighing droplets formed during a period of 20 to 40 seconds. The Brilliant Blue and Saturn Yellow mixture at $0.15 \%$ was stable under all conditions tested. It was not absorbed by the leaves and maintained the same surface tension as that of water, thus permitting concentration adjustment to the same levels used for agrochemical products, and allowing the development of a qualitative method based on visual evaluation of the distribution of the pigment under ultraviolet light and of a quantitative method based on the determination of the amount of the dye deposited in the same solution. Spray deposition could be evaluated at different surface tensions of the spraying solution, simulating the effect of agrochemical formulations.

Key words: pesticide application, deposition assessment, tracer, citrus trees

\section{ESCOLHA DE TRAÇADORES PARA AVALIAÇÃO DE DEPÓSITOS DE PULVERIZAÇÃO}

\begin{abstract}
RESUMO: As substâncias traçadoras são usadas para avaliar a eficácia de pulverizações mas, normalmente, elas modificam a tensão superficial de soluções aquosas. $O$ trabalho objetivou definir um método para avaliar a distribuição e a quantidade de produto depositada em pulverizações, utilizando-se substâncias traçadoras, com a possibilidade de ajustar a tensão superficial da calda. Foram testados os produtos Azul Brilhante a 0,15\%, Saturn Yellow a 0,15\% suspenso em lignosulfonato Vixilperse a 0,015\% e a Fluoresceína Sódica a 0,005\%, e as misturas de Azul Brilhante mais Saturn Yellow e Azul Brilhante mais Fluoresceína, nas mesmas concentrações. Para avaliar a degradação as soluções com os produtos foram depositados sobre folhas de citros e avaliados as quantidades através da leitura de unidade de fluorescência e densidade óptica, das soluções sem secar, secas no escuro, exposta ao sol por 2, 4 e 8 horas e comparadas com as leituras obtidas com os depósitos direto em água. A tensão superficial da solução traçadora foi determinada pela passagem de gotas formadas no período entre 20 e 40 segundos. A mistura do Azul Brilhante mais o Saturn Yellow a 0,15\%, não apresentou degradação em todas as condições de avaliação, não foi absorvida pelas folhas e manteve a solução na mesma tensão superficial da água, possibilitando ajustá-la aos mesmos níveis das concentrações dos produtos fitossanitários. Isto proporcionou o estabelecimento de um método qualitativo pela avaliação visual sobre luz ultravioleta da distribuição do pigmento e quantitativo com a determinação da quantidade depositada do corante numa mesma solução, em diferentes tensões superficiais na calda de pulverização.

Palavras-chave: aplicação de pesticidas, avaliação da deposição, traçador, citros
\end{abstract}

\section{INTRODUCTION}

The distribution and amount of product deposited on the target determines the success of phytosanitary practices. Many studies have compared the efficiency of different spraying devices or determined the best operational conditions of a single device. However, more precise and efficient methodologies are required to assess the performance of different spraying devices regarding distribution and amount of product deposited on the target. 
Two basic methodologies are used for the evaluation of spraying effectiveness. The first, quantifies deposition without visualizing the distribution, using metals, tracer and nutrients (Byers et al., 1984; Sutton \& Unrath, 1984; Salyani, 1988; Val Monterola et al., 1988), dyes (Johnstone, 1977; Pergher et al., 1997; Salyani \& Whitney, 1988; Hayden et al., 1990; Koch, 1993; Koch et al., 1996), or the active ingredient (Matuo, 1988; Smelt et al., 1993). The second is based on the visualization of distribution, without determining the amount of deposit, using fluorescent pigments under ultraviolet light (UV) (Staniland, 1959; Edwards et al., 1961; Pereira, 1967; Sharp, 1974). Salyani \& Whitney (1988) consider the latter method to be simple, fast and suitable for the determination of large differences in coverage, but highly subjective for more detailed studies. Image analysis, which recognizes a tracer applied to and deposited on the target, has emerged as a method for the determination of the amount of and total area covered by the spray (Carlton et al., 1981; Sistler et al., 1982; Last \& Parkin, 1987; Furness \& Newton, 1988; Evans et al., 1994).

These methods, however, do not consider variations in the surface tension of the solution to be applied which, according to Lefebvre (1993), is an important property in droplet size and distribution over spraying surfaces. Fluorescent pigments used as tracers are not water soluble and require the addition of surfactants, which reduce the surface tension of the solution.

Information about spraying efficiency should include data on the amount and distribution of deposits on the target (Nordby, 1989). Quantitative analyses have been used to evaluate spraying performance, but this method determines solely the amount of product deposited, and do not provide information on distribution (Evans et al., 1994). Therefore, methods that allow simultaneous determination of distribution and amount of spray deposits, are better tools for evaluating the efficiency of phytosanitary treatments.

The objective of the present study was to establish a method for both qualitative and quantitative evaluation of spray deposition using tracer substances, with the possibility of adjusting the surface tension of the solution in order to evaluate the effect of different formulations of agrochemicals.

\section{MATERIAL AND METHODS}

The study was carried out in Botucatu-SP, Brazil (22 $51^{\prime} ' \mathrm{~S}$ and $\left.48^{\circ} 26^{\prime} \mathrm{W}\right)$. Citrus plants, Citrus sinensis L. var. Hamlin, were sprayed with a tracer solution composed of Brilliant Blue and Saturn Yellow at $0.15 \%$ dissolved in Vixilperse at $0.015 \%$. Spraying was carried out with an air-carrier sprayer at $1830 \mathrm{~L} \mathrm{ha}^{-1}$. The concentrations of the tracer products were as follows: $0.15 \%$ Brilliant Blue food dye (FD\&C No. 1); 0.15\% Saturn Yel- low (Ax-17) suspended in $0.015 \%$ sugar-free and oxidized sodium lignosulfonate (Vixilperse), and 0.005\% sodium fluorescein. The mixtures were Brilliant Blue and Saturn Yellow dissolved in Vixilperse and Brilliant Blue and fluorescein at the same concentrations.

The Saturn Yellow-Vixilperse lignosulfonate suspension was obtained by the following procedure: a premixture of the macerated products as dry powder was prepared; as little water as possible was then added as droplets, continuous stirring, until a completely wet, dense paste was formed; the final volume of water then added. The surface tension of the aqueous solutions containing the products and mixtures (treatments), was measured by weighing the droplets produced for 20 to 40 seconds (to the nearest 0.001 ), using a $25 \mathrm{~mL}$ burette (Mendonça et al., 1999; Costa, 1997).

Plants were divided in twelve plots. Sets were taken inside and outside these plots from the lowest, medium and highest third of the plants located in front and perpendicularly to the spraying direction. In each canopy position, 50 leaves were collected to evaluate spray quality on both sides.

Qualitative determination of spray distribution was done by visual evaluation of the fluorescent tracer under UV. Leaf deposits were classified recommended by Palladini (1990) and Raetano (1996): grade 0 - no deposition; grade 1 - surface containing traces of the deposit; grade 2 - low deposition throughout the leaf; grade 3 mild deposition on $1 / 3$ of the leaf; grade 4 - mild deposition throughout the leaf; grade 5 - medium deposition on half the leaf; grade 6 - medium deposition throughout the leaf; grade 7 - deposition on $2 / 3$ of the leaf; and grade 8 - high deposition throughout the leaf.

The spraying uniformity was evaluated with the spray penetration index defined by Palladini (1990) and Raetano (1996). This index measures the relationship between spray deposits inside and outside plant canopies in different positions.

Values of the Brilliant Blue deposits were obtained in leaves washing solution or directly in water. For washing solution, five sets of 20 leaves were used for each product or mixture. Leaves were placed individually in 40-mL plastic flasks containing approximately one third of water, in a way that the petiole and part of the leaf were immersed in water to prevent dehydration. Twenty microliters of the solution were placed on each leaf in the form of small droplets with a $50-\mu \mathrm{L}$ microsyringe. When the aqueous solution contained Saturn Yellow, a product that decants without shaking, homogeneity of the $20-\mu \mathrm{L}$ set was achieved by shaking the solution in a $200-\mathrm{mL}$ beaker in a magnetic shaker at 50 rpm. Solutions containing Brilliant Blue or fluorescein without Saturn Yellow did not require this procedure since they are highly soluble in water. 
Fluorescence and absorbance of the products were determined in a Biotek FL600FA fluorescence and absorbance reader. A fluorescence filter $(485 \mathrm{~nm}$ excitation and $530 \mathrm{~nm}$ emission) was used for fluorescein and the Saturn Yellow tracer; optical density filter $(630 \mathrm{~nm})$ was used for the Brilliant Blue dye.

Degradation of the tracers by the leaves was determined for each product and mixtures using different wavelengths to avoid measuring interference between products. The first assessment was obtained for one leaf sample of each solution without drying. To deem doubts between product degradation and absorption by the leaves, all other samples were kept in the dark at $24^{\circ} \mathrm{C}$, $62 \%$ relative humidity, until droplets were dry, and a second assessment was obtained for one additional sample.

The remaining samples were exposed to sunlight for either 2,4 or $8 \mathrm{~h} \mathrm{(10h00} \mathrm{to} 18 \mathrm{~h} 00)$, so that all treatments received sunlight for 8 hours. In the $2 \mathrm{~h}$-exposure treatment, samples were exposed to sunlight for 15 min and then left in the dark for $45 \mathrm{~min}$, each hour. For the 4-h treatment, samples were alternately exposed to sunlight dark for $1 \mathrm{~h}$; for the 8 -h treatment, leaves remained exposed to sunlight throughout the period.

Stability and the time lag between the application and field collection of samples were determined by comparing fluorescence and optical density units of the single products and mixtures obtained in the absence and presence of sunlight during different periods of exposure. To remove deposits, leaves were placed individually in 12 $\times 25 \mathrm{~cm}$ polyethylene bags containing $10 \mathrm{~mL}$ distilled water and $1 \%$ of the surfactant Iharaguem-S, a solution previously shown not to interfere with the results. Samples of the washing solution for leaves of $1.5 \mathrm{~mL}$ were placed in 24-well culture plates. Values of optical density (absorbance) and fluorescence units, as well as confidence intervals, were obtained for 100 replications in a programming of the reader equipment. Confidence intervals were determined by $\mathbf{t}$ test $(\alpha=0.1)$.

\section{RESULTS AND DISCUSSION}

The solutions of $0.005 \%$ sodium fluorescein, $0.15 \%$ Saturn Yellow dissolved in $0.015 \%$ Vixilperse, $0.15 \%$ Brilliant Blue, and the mixtures of $0.005 \%$ fluorescein $+0.15 \%$ Brilliant Blue and $0.15 \%$ Saturn Yellow $+0.15 \%$ Brilliant Blue (Figure 1) did not alter surface tension of solutions. Therefore, the products can be used as tracers in the absence of surfactants.

To determine the fluorescence stability and interval between application and sampling, a tracer with natural exposure to $21.3 \mathrm{~mJ} \mathrm{~m}^{-2}$ sun radiation, was used to assess the degradation of the tracers under sunlight. Higher fluorescence units of pigments alone and in a mixture with Brilliant Blue were observed when the results were obtained directly in the water (Table 1) rather than in the solution, directly after washing the leaves. Approximately $25 \%$ reduction in fluorescence units was observed for leaf deposits compared to values directly obtained in water, even when leaves were not dried. Leaf deposits dried in the dark and exposed to light for 2, 4 and $8 \mathrm{~h}$ showed continuing and differing reduction in fluorescence. After $8 \mathrm{~h}$ under light, fluorescence values were reduced by half in comparison to those obtained directly in water. Fluorescence units of fluorescein and Brilliant Blue mixture were similar, both for the deposits measured directly in water and after $8 \mathrm{~h}$ exposure to sunlight (Table 1). However, a reduction of approximately one third in

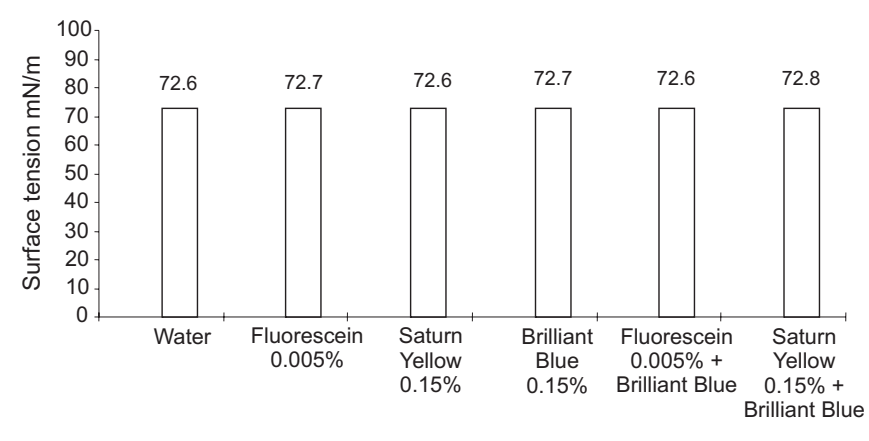

Figure 1 - Surface tension of the products and mixtures used as tracers for the evaluation of spray deposition.

Table 1 - Fluorescence units and confidence interval of deposits containing fluorescein and Saturn Yellow on their own and as a mixture with Brilliant Blue obtained directly in water, for leaves without drying, for leaves dried in the dark and for leaves exposed to sunlight for 2,4 and $8 \mathrm{~h}$.

\begin{tabular}{llccc}
\hline \multirow{2}{*}{ Condition } & \multicolumn{4}{c}{ Tracer and mixture } \\
\cline { 2 - 5 } & Fluorescein & Fluorescein + Brilliant Blue & Saturn Yellow & $\begin{array}{c}\text { Saturn Yellow }+ \\
\text { Brilliant Blue }\end{array}$ \\
\hline Directly in water & $4884.0 \pm 56.2$ & $4805.9 \pm 61.7$ & $5317.9 \pm 86.1$ & $5390.9 \pm 65.3$ \\
Leaf without drying & $3642.4 \pm 95.4$ & $3272.8 \pm 138.8$ & $5004.1 \pm 189.8$ & $5179.3 \pm 78.7$ \\
Leaf dried in the dark & $3095.1 \pm 64.7$ & $3093.4 \pm 72.8$ & $5017.4 \pm 153.4$ & $5024.8 \pm 182.9$ \\
Leaf exposed to 2-h sunlight & $2710.8 \pm 111.9$ & $2968.6 \pm 116.9$ & $4824.7 \pm 127.8$ & $5034.6 \pm 126.5$ \\
Leaf exposed to 4-h sunlight & $2936.4 \pm 61.9$ & $3133.5 \pm 65.7$ & $5068.9 \pm 109.8$ & $5143.3 \pm 82.1$ \\
Leaf exposed to 8-h sunlight & $2560.9 \pm 108.7$ & $2528.7 \pm 87.0$ & $5125.8 \pm 120.5$ & $5171.0 \pm 118.2$ \\
\hline
\end{tabular}

Sci. Agric. (Piracicaba, Braz.), v.62, n.5, p.440-445, Sept./Oct. 2005 
fluorescence units was observed for wet leaf deposits, in comparison to deposits measured directly in water. Leaves dried in the dark either exposed or not to light for 2 and $4 \mathrm{~h}$, yielded similar values, considering the confidence interval.

Regarding the Saturn Yellow pigment alone or mixed with Brilliant Blue, higher fluorescence units were observed for the deposits measured directly in water (Table 1). However, for the leaf deposits containing only Saturn Yellow, similar values of fluorescence units were obtained for wet leaves, for leaves dried in the dark and for leaves exposed to light for 2 and $4 \mathrm{~h}$. Similar values were also obtained for all conditions of deposition when Saturn Yellow was mixed with Brilliant Blue.

With respect to the optical density (absorbance) of the Brilliant Blue solution, higher values were observed for the deposits measured directly in water compared to the washed leaf solutions (Table 2). Gradual and different reduction in optical density occurred under the other conditions and during light exposure, considering the confidence intervals. In the case of Brilliant Blue + fluorescein, optical density decreased with increasing exposure interval. Behavior was similar to that observed for the dye alone. Optical densities of Brilliant Blue + Saturn Yellow were similar in all deposition conditions and exposure to light. There was no degradation of the substances under sunlight or absorption by the leaves when the mixture was used.
Because the optical density and fluorescence units of the $0.15 \%$ Brilliant Blue and $0.15 \%$ Saturn Yellow mixture were stable both in water and in leaf deposits under the different conditions, an additional test was carried out using only this mixture at the same concentrations to check reproducibility of the optical density and fluorescence reading. Initially, all solutions were kept in the dark before drying for subsequent light exposure. In the second test, an additional sample of 20 leaves was used to evaluate the possibility of product degradation between deposition and drying under sunlight $(25.1 \mathrm{~mJ}$ $\mathrm{m}^{-2}$ ).

Results shown in Table 3 confirmed the fluorescence and optical density values previously obtained, and values did not differ. Differences were observed only for absolute optical density values of the mixture (Tables 1 and 2), while no differences in optical density were observed regarding the different conditions to which solutions were exposed. These differences in measurements probably result from variations in the weighed amount and/or volume of the solution used.

The mixture $0.15 \%$ Brilliant Blue $+0.15 \%$ Saturn Yellow dissolved in $0.015 \%$ Vixilperse was stable under sunlight and was not absorbed by the leaves up to $8 \mathrm{~h}$ (Tables 2 and 3) allowing sufficient time to collect field samples. Solutions surface tension equaled water (Figure 1), and results did not differ $(P<0.01)$. This solution, therefore, satisfies the objectives of the study and

Table 2 - Optical density (absorbance) and confidence interval of deposits containing Brilliant Blue on its own and as a mixture with fluorescein and Saturn Yellow obtained directly in water, for leaves without drying, for leaves dried in the dark and for leaves exposed to sunlight for 2,4 and $8 \mathrm{~h}$.

\begin{tabular}{lccc}
\hline \multirow{2}{*}{ Condition } & \multicolumn{3}{c}{ Tracer and mixture } \\
\cline { 2 - 4 } & Brilliant Blue & Brilliant Blue + Fluorescein & Brilliant Blue + Saturn Yellow \\
\hline Directly in water & $0.406 \pm 0.001$ & $0.397 \pm 0.002$ & $0.382 \pm 0.004$ \\
Leaf without drying & $0.396 \pm 0.002$ & $0.393 \pm 0.002$ & $0.378 \pm 0.003$ \\
Leaf dried in the dark & $0.393 \pm 0.003$ & $0.383 \pm 0.002$ & $0.380 \pm 0.004$ \\
Leaf exposed to 2-h sunlight & $0.376 \pm 0.002$ & $0.386 \pm 0.002$ & $0.380 \pm 0.009$ \\
Leaf exposed to 4-h sunlight & $0.372 \pm 0.003$ & $0.376 \pm 0.007$ & $0.381 \pm 0.005$ \\
Leaf exposed to 8-h sunlight & $0.350 \pm 0.004$ & $0.361 \pm 0.004$ & $0.380 \pm 0.006$ \\
\hline
\end{tabular}

Table 3 - Fluorescence units and optical density (absorbance) confidence interval of deposits containing the Brilliant Blue and Saturn Yellow mixture obtained directly in water, for leaves without drying, for leaves dried in the dark, for leaves dried under sunlight and for leaves exposed to sunlight for 2, 4 and $8 \mathrm{~h}$.

\begin{tabular}{lll}
\hline Condition & Fluorescence units & Optical density \\
\hline Directly in water & $4968.8 \pm 101.7$ & $0.356 \pm 0.004$ \\
Leaf without drying & $4980.0 \pm 116.5$ & $0.358 \pm 0.003$ \\
Leaf dried in the dark & $5015.4 \pm 183.2$ & $0.354 \pm 0.004$ \\
Leaf dried under sunlight & $4854.0 \pm 113.6$ & $0.355 \pm 0.004$ \\
Leaf exposed to 2-h sunlight & $4736.1 \pm 159.7$ & $0.350 \pm 0.005$ \\
Leaf exposed to 4-h sunlight & $4769.7 \pm 97.4$ & $0.352 \pm 0.005$ \\
Leaf exposed to 8-h sunlight & $4697.9 \pm 137.8$ & $0.350 \pm 0.005$ \\
\hline
\end{tabular}


Table 4 - Frequency (\%) of grade attributed to spray distribution by visual evaluation in upper and lower surfaces of citrus leaves after Brilliant Blue and Saturn Yellow mixture spraying on citrus trees at different positions of the tree canopy.

\begin{tabular}{llrrrrrrrrr}
\hline \multirow{2}{*}{ Position of the tree } & \multicolumn{7}{c}{ Leaf Surface } & \multicolumn{7}{c}{ Frequency $(\%)$ of spray distribution to each grade } \\
\cline { 3 - 10 } & & 0 & 1 & 2 & 3 & 4 & 5 & 6 & 7 \\
\hline \multirow{2}{*}{ Lowest third } & Upper & 0.0 & 1.0 & 4.0 & 2.5 & 39.5 & 2.0 & 30.5 & 0.5 & 20.0 \\
& Lower & 0.5 & 10.0 & 33.0 & 5.0 & 23.5 & 4.0 & 17.0 & 0.5 & 6.5 \\
\hline \multirow{2}{*}{ Medium third } & Upper & 0.0 & 0.0 & 5.0 & 1.0 & 29.5 & 2.0 & 40.0 & 3.5 & 19.0 \\
& Lower & 0.5 & 4.0 & 9.5 & 4.0 & 21.0 & 8.0 & 22.5 & 1.5 & 29.0 \\
\hline \multirow{2}{*}{ Highest third } & Upper & 0.0 & 1.0 & 16.0 & 6.5 & 38.5 & 6.5 & 24.0 & 0.0 & 7.5 \\
& Lower & 0.0 & 3.0 & 18.5 & 7.0 & 24.0 & 9.0 & 27.5 & 3.5 & 7.5 \\
\hline
\end{tabular}

Table 5 - Spray penetration index in different regions of the citrus tree: lowest third (L), medium third (M) and highest third $(\mathrm{H})$; front $(\mathrm{F})$ and perpendicularly $(\mathrm{P})$ to the spraying way; inside (I) and outside $(\mathrm{O})$ of canopy; in the upper and lower surface of the citrus leaves.

\begin{tabular}{lcccc}
\hline Region of the tree & $\begin{array}{c}\text { Leaf } \\
\text { surface }\end{array}$ & LI/LO & MI/ME & HI/HO \\
\hline Front (F) & upper & 1.09 & 1.09 & 0.98 \\
& lower & 0.84 & 0.79 & 0.93 \\
\hline Perpendicularly (P) & upper & 1.19 & 1.02 & 1.02 \\
& lower & 0.60 & 0.90 & 0.92 \\
\hline Mean - (F) $+(\mathrm{P})$ & upper & 1.14 & 1.06 & 1.00 \\
Mean - (F) $+(\mathrm{P})$ & lower & 0.72 & 0.85 & 0.92 \\
\hline
\end{tabular}

can be used as qualitative method for assessing spray distribution on the target under UV (Tables 4 and 5). Lower variability of spray distribution was observed on leaves positioned in the highest third of citrus trees when both leaf surfaces were evaluated. Only $7.5 \%$ showed high deposition throughout the leaf (Table 4). The solution can be also used as quantitative method of measuring fluorescence units of Saturn Yellow pigment and optical density of Brilliant Blue dye in deposits removed from the target area. The mixture also enables altering surface tension of the tracer solution can by adding surfactants. Additives can be mixed until the ideal concentrations of the agrochemical products are reached.

The spray penetration index showed greater deposition on upper surfaces of leaves positioned in the lowest third of plants (Table 5). Higher uniformity of spray distribution was obtained in leaves positioned in the highest third of the trees. The desirable index for this relationship must be as near to one as possible (Matuo, 1988).

Results agree with requirements defined by Cooke \& Hislop (1993). The ideal tracer for the evaluation of spray distribution is a substance that can be visualized in the dry and can be recovered quantitatively from the natural or artificial surface. Data are also in accordance with results reported by Sharp (1974), who ob- served that the degradation of the Saturn Yellow pigment was less than $5 \%$ after exposure to solar radiation, equivalent to $6 \mathrm{~h}$ of sun in a full, English summer, and by Yates \& Akesson (1963), who pointed out that the selected tracer needs to be stable under the environmental conditions during the experiments.

\section{REFERENCES}

BYERS, R.E.; LYONS JR., C.G.; YODER, K.S.; HORSBURGH, R.L.; BARDEN, J.A.; DONOHUE, S.J. Effects of apple tree size and canopy density on spray chemical deposit. HortScience, v.19, p.93-94, 1984.

CARLTON, J.B.; BOUSE, L.F.; O’NEAL, H.P.; WALLA, W.J. Measuring spray coverage on soybean leaves. Transactions of the ASAE, v.24, p.1108-1110, 1981.

COOKE, B.K.; HISLOP, E.C. Spray tracing techniques. In: MATTHEWS, G.A.; HISLOP, E.C. Application technology for crop protection. Wallingford: CAB, 1993. p.85-100.

COSTA, E.A.D. Efeitos de surfatantes sobre a tensão superficial de soluções de rodeo. Botucatu: UNESP/FCA, 1997. 73p. (Dissertação - Mestrado).

EDWARDS, G.J.; THOMPSON, W.L.; KING, J.R.; JUTRAS, P.J. Optical determination of spray coverage. Transactions of the ASAE, v.4, p.206207, 1961

EVANS, M.D.; LAW, S.E.; COOPER, S.C. Fluorescent spray deposit measurement via light intensified machine vision. Applied Engineering in Agriculture, v.10, p.441-447, 1994.

FURNESS, G.O.; NEWTON, M.R. A leaf surface scanning technique using a fluorescence spectrophotometer for the measurement of spray deposits. Pesticide Science, v.28, p.123-137, 1988.

HAYDEN, J.; AYERS, G.; GRAFIUS, E.; HAYDEN, N. Two water-soluble optically resolvable dyes for comparing pesticide spray distribution. Journal of Economic Entomology, v.83, p.2411-2413, 1990.

JOHNSTONE, D.R. A twin tracer technique permitting the simultaneous evaluation of the field performance of two spraying machines or spraying techniques. Journal of Agricultural Engineering Research, v.22, p.439-443, 1977.

$\mathrm{KOCH}, \mathrm{H}$. Application rate and spray deposit on targets in plant protection. In: SYMPOSIUM INTERNATIONAL SUR LES TECHNIQUES D'APPLICATION DES PRODUITS PHYTOSANITAIRES, 2., Strasbourg, 1993. Annales. Strasbourg: British Crop Protection Council, 1993. p.175-182.

KOCH, H.; WEISS, P.; GUENDEL, L.; SCHIETINGER, R. Untersuchung der Belagsbildung an morphologisch unterschiedlichen Salatsorten im Hinblick auf die Bewertung von Pflanzenschutzmittelrueckstaeden. Nachrichtenblatt des Deutschen. Pflanzenschutzdienstes, v.48, p.117120, 1996

LAST, A.J.; PARKIN, C.S. The measurement of spray deposits on natural surfaces by image analysis. Aspects of Applied Biology, v.14, p.85-96, 1987.

LEFEBVRE, A.H. Droplet production. In: MATTHEWS, G.A.; HISLOP, E.C. Application technology for crop protection. Wallingford: $\mathrm{CAB}$, 1993. p.85-100. 
MATUO, T. Desenvolvimento de um pulverizador intermitente operado fotoeletricamente para tratamento de pomares de citros. Jaboticabal: UNESP/FCAV, 1988. 167p. (Tese - Livre Docência).

MENDONÇA, C.G.; VELINI, E.D.; MARTINS, D.; MENDONÇA, C.G. Efeitos de surfatantes sobre a tensão superficial e a área de molhamento de soluções de glyphosate sobre folhas de tiririca. Planta Daninha, v.17, p.355-365, 1999.

NORDBY, A. Application and control of the distribution of plant nutrients and pesticides. In: DODD \& GRACE, (Ed.) Land and water use. Roterdam: Balkema, 1989. p.2073-2079.

PALLADINI, L.A. Efeito de condições operacionais de um turboatomizador na cobertura de folhas de citros. Jaboticabal: UNESP/FCAV, 1990. 93p. (Dissertação - Mestrado).

PEREIRA, J.L. Uses of fluorescent tracer for assessment of spray efficiency. Kenya Coffee, v.12, p.461-465, 1967.

PERGHER, G.; GUBIANI, R.; TONETO, G. Foliar deposition and pesticide losses from three air-assisted sprayers in a hedgerow vineyard. Crop Protection, v.16, p.25-33, 1997.

RAETANO, C.G. Condições operacionais de turboatomizadores na distribuição e deposição da pulverização em citros. Piracicaba: USP/ ESALQ, 1996. 93p. (Tese - Doutorado).

SALYANI, M. Droplet size effect on spray deposition efficiency of citrus leaves. Transactions of the ASAE, v.31, p.1680-1684, 1988.

SALYANI, M.; WHITNEY, J.D. Evaluation of methodologies for field studies of spray deposition. Transactions of the ASAE, v.31, p.390395, 1988.

SHARP, R.B. Spray deposit measurement by fluorescence. Pesticide Science, v.5, p.197-209, 1974.
SISTLER, F.E.; SMITH, P.A.; RESTER, D.C. An image analyzer for aerial application patterns. Transactions of the ASAE, v.25, p.885-887, 1982.

SMELT, J.H.; SMIDT, R.A.; HUIJSMANS, J.F.M. Comparison of spray deposition on apple leaves of captan and the dye brilliant sulfoflavine. In: SYMPOSIUM INTERNATIONAL SUR LES TECHNIQUES D'APPLICATION DES PRODUITS PHYTOSANITAIRES, 2. Strasbourg, 1993. Annales. Strasbourg: British Crop Protection Council, 1993. p.191-197.

STANILAND, L.N. Fluorescent tracer techniques for the study of spray and dust deposits. Journal of Agricultural Engineering Research, v.4, p.100-125, 1959.

SUTTON, T.B.; UNRATH, C.R. Evaluation of the Tree-Row-Volume concept with density adjustments in relation to spray deposits in apple orchards. Plant Disease, v.68, p.480-484, 1984.

VAL MONTEROLA, L.; JUSTE PEREZ, F.; FORNES CHULIÁ, I.; VILLOLDO BELLÓN, O.; IBÁNÉZ, R. Penetracion y tamaño de gota en hoja de distintos sistemas de distribucion de Productos fitosanitarios en cultivos citricos. In: CONFERENCIA INTERNACIONAL DE MECANIZACIÓN AGRARIA, 20., Zaragoza, 1988. Zaragoza:Associacion Nacional de Ingenieros Agrónomos, 1988. p.201207.

YATES, W.E.; AKESSON, N.B. Fluorescent tracers for quantitative microresidue analysis. Transactions of the ASAE, v.6, p.105-114, 1963

Received February 16, 2004

Accepted June 29, 2005 